\title{
Introduction: (De)democratisation in Slovenia and Montenegro: Comparing the Quality of Democracy
}

\author{
OLIVERA KOMAR AND META NOVAK ${ }^{1}$
}

\section{sciendo}

Politics in Central Europe (ISSN: 1801-3422)

Vol. 16, No. 3

DOI: $10.2478 /$ pce-2020-0026

\begin{abstract}
This paper creates a framework for the comparison of two similar and yet different democratisation cases - Slovenia and Montenegro. The two countries have obvious similarities: their geography and small population, as well as their common socialist Yugoslav heritage and common aspirations to join international organisations, most importantly the European Union. However, while Slovenia went through the democratisation process rather smoothly, Montenegro took the longer road, struggling for more than a decade to regain its independence and complete its transition. We take into account different internal and external factors in these two cases such as the year of independence and of joining NATO, the political and electoral system, ethnic homogeneity, the viability of civil society, EU integration status, economic development and the presence of war in each territory in order to identify and describe those factors that contributed to the success of democratisation in different areas: the party system, the interest groups system, the defence system, Europeanisation and social policy. We find that the democratisation process in these countries produced different results in terms of quality. Various objective measures of the quality of democracy score Slovenia higher compared to Montenegro, while public opinion data shows, in general, greater satisfaction with the political system and greater trust in political institutions in Montenegro than in Slovenia.
\end{abstract}

Keywords: democratisation, democratic backsliding, post-socialism, quality of democracy

1 The authors acknowledge financial support from the Slovenian Research Agency through research funding No. P5-0136 and BI-ME/18-20-030 and from Ministry of Science, Government of Montenegro no. 01-396/2 dated 20-07-2018. 


\section{Introduction}

After the disintegration of Yugoslavia in the 1990s, its successor states initiated democratization process. However, democratization occurred at a different pace in each country, depending on both the internal and the external context (Beetham 2004).

Slovenia went through the process of democratisation rather successfully (Rizman, 2006) due to a number of factors. First of all, it took advantage of its significantly better economic position compared to the other Yugoslav republics. The advantage of Slovenia especially in its economic situation was already evident in the1990s and continues to be the case today. Croatia, which was the second ex-Yugoslav country to join the European Union (EU) still lags behind Slovenia on most economic indexes. This better economic position contributed to the easier transformation to free market economy and a smoother process of democratic transition. Its border position with Western Europe (having frontiers with both Austria and Italy) broadened the perspective of its citizens and their ambition to change the political system. Moreover, with its rather homogeneous population, Slovenia was spared internal disputes over key strategic goals. As the result its accession to the international organisation community followed immediately after independence and occurred simultaneously with its democratic transition. Slovenia entered international organisations rather quickly, joining the United Nations in 1992, the Council of Europe in 1993, the European Union and NATO in 2004 and the OECD in 2010.

On the other hand, Montenegro, the smallest of the former Yugoslav republics, is one of the youngest independent countries in Europe. After the dissolution of Yugoslavia, it did not seek full independence until 2006. In the 1990 s, it chose to followed Milosevic's politics and stay in various different associations with Serbia. Due to its heterogeneous population and ethnic based political cleavage, it did not resolve its statehood status before 2006. Even after independence, the cleavage has persisted in driving the political dynamic now disguised in other issues (for and against NATO, for and against the EU, for and against the independence of Kosovo, for and against the controversial law on the freedom of religion, and so on). In 2006, Montenegro joined United Nations, in 2007 it joined to the Council of Europe, and ten years later, in 2017 Montenegro became a member of NATO. In 2012 Montenegro started the process of accession negotiations with the EU and currently has the status of an EU candidate country. Unlike Slovenia, its only external border was with communist Albania, a country that also experienced political change and began its democratic transition in 1991. The economic situation of Montenegro was much less positive than it was in Slovenia. However, both GDP and the Human Development Index have been slowly increasing since 2000 and are the highest after Slovenia and Croatia among the former Yugoslav republics 
(Human Development Report 2019). Additionally, Montenegro is yet to experience a change in government. The ruling party which originated in the former Montenegrin Communist party has been in power ever since. Bearing in mind Huntington's 'two turnover test' (Huntington 1991), one could even argue that democracy in Montenegro is yet to consolidate.

However, even after a successful democratic transition and consolidation, the process is never fully complete, as it continues towards establishing a higher degree of quality of democracies and increasing the legitimacy of adopted policies (Högström 2011). Nowadays many European countries face democratic deficits, as is evident from voter turnout in elections, party membership, and trust in political institutions and parties (Maloney 2009). Furthermore, researchers have shown that established democracies are facing democratic backsliding or de-democratisation processes (Bermeo 2016; Bieber Solska - Taleski 2018; Günay - Dzihic 2016; Levitsky - Way 2010; Öktem - Akkoyunlu 2016; Zakaria 1997). The examples of democratic deficit and possible backslidings need to be taken even more into account in young democracies such as Slovenia and Montenegro. This article and special issue will thus focus on the case studies of Slovenia and Montenegro in order to see how the heritage and legacy of different democratisation processes reacts to contemporary de-democratisation challenges. Montenegro and Slovenia have many common characteristics which enables us to "isolate" the effects of different processes and dynamics of democratisation and evaluate how resistant the newly built systems are to current democratic backsliding treats.

The two countries share a recent socialist past and a specific Yugoslav soft self-governance system. They are both small in terms of population and area, and they both went through the process of political change in the 1990s that ended up in independence. In Slovenia, this process was completed rather swiftly while Montenegro took a longer path. In addition, both countries are parliamentary democracies with proportional representation.

Beyond these common characteristics, within the framework of this special issue, we intended to identify the factors that have contributed to the current level and quality of democracy in Slovenia and Montenegro and compare the level of quality of democracy in different areas. In this introductory article to the special issue, we will present the existing empirical evidence with regards to the current quality of democracy in the two countries and the authors of the papers which follow will then look in more detail at the factors that have contributed to the quality of democracy in different areas, as well as at the resilience of the exiting political culture and structures when faced with current de-democratisation challenges. 


\section{How do we define the quality of democracy?}

During the 1990s, the majority of Central and Eastern Europe, which had experienced communist rule, went through the process of democratic transition and changes to the political system. Today, the majority of Europe consists of democratic countries that are either currently viewed as consolidated democracies (Slovenia, the Czech Republic, Estonia, Latvia, Lithuania and Slovakia), semi-consolidated democracies (Poland, Bulgaria, Croatia, Romania) or transitional governments/hybrid regimes (Hungary, Montenegro, Albania, Bosnia and Herzegovina, Serbia, Kosovo and North Macedonia) (Nations in Transit, 2020). Some of the countries exhibited change of the status in the last two years. Poland went from consolidated democracy to semi-consolidated democracy, Hungary, Serbia and Montenegro from semi-consolidated to transitional/hybrid regime (Nations in Transit, 2020). At the same time, the quality of democracy is being questioned in older "established" democracies as well. Trust in political institutions and especially political parties is dropping. The same can be said for levels of satisfaction with democracy, especially as a result of recent economic crises (Eurobarometer 2019). Scholars are thus no longer only interested in explaining regime transition and measuring the success of various democratic transitions, but also in evaluating and explaining the quality of democracy.

Measuring the quality of democracy could also be useful for political actors and civil society actors. After all, deepening democracy is perceived as being of vital importance to increasing the legitimacy of political and policy decisions (Diamond - Morlino 2004a). Low levels in relation to the quality of democracy, on the other hand, might indicate a serious democratic problem (Högström 2011). As such, it is no surprise that we can come across various measures of quality of democracy (Fuchs - Roller 2018). However, this does not mean that the definition of the quality of democracy is universal. In fact, researchers in this field have not yet agreed on a single definition (Högström 2011). One of the most straightforward definitions is: "The term "quality" refers to the degree to which a system meets such democratic norms as representativeness, accountability, equality and participation." (Lijphart 1993: 14).

While researchers agree that the quality of democracy is composed of measure that consists of multiple dimensions, they have not all used the same dimensions and indicators of democracy. As we noted, the quality of democracy is affected by different factors and dimensions, and some of them are closely dependent on the satisfaction and interests of citizens. Predominantly these includes the following dimensions:

1) Freedom, which includes political, civil and social rights such as the right to political participation, human rights and socioeconomic rights;

2) The rule of law, "the legal system [that] defends the political rights and procedures of democracy, upholds everyone's civil rights, and reinforces the authority of 
other agencies of horizontal accountability that ensure the legality and propriety of official actions" (Diamond - Morlino 2004b: 23).

3) Vertical accountability, where politicians need to justify their decisions before voters;

4) Responsiveness, the satisfaction of citizens with democracy as well as the implementation of policies that citizens support;

5) Equality, being the legal equality of all citizens regardless of their gender, race, ethnicity, religion, political orientation and so on;

6) Participation, where every citizen has the right to participate politically and is able to use this right. This includes not only voting but also the right to organize, assemble, protest, monitor, demanding accountability and lobby for your own interests;

7) Competition, being regular, free and fair multiparty electoral competition;

8) Horizontal accountability, where politicians are also answerable to other officials and institutions;

9) Transparency and

10) Effectiveness of representation (Diamond - Morlino 2004b).

This is of course not necessarily an exhaustive list of dimensions. Moreover, the above listed dimensions often overlap and depend upon one another. This means that improvements in one dimension thus not lead only to improvements in the quality of democracy in general but also in other dimensions, causing a multiplying effect in the improvement of the quality of democracy. Likewise, the regression of one dimension may lead also to regression in the other dimensions. At the same time, there are also some trade-offs between different dimensions, which means that it is impossible to maximise all dimensions at once, for example in the opposition between freedom and responsiveness. Consequently, there is no single best state of democracy that each country should reach (Diamond - Morlino 2004b).

Additionally, a government may achieve high scores on all dimensions while the constituency may still not be satisfied with the outcomes, since it is impossible for the government to take in consideration all possible interests (Diamond Morlino 2004b). It is thus possible that objective measures of individual dimensions score highly while the subjective measures show low scores or vice-versa (Fuchs - Roller 2018). Indexes of the quality of democracy are predominantly based on objective measures and there are several: these include the indices provided by Freedom House, Polity IV, the Economist Intelligence Unit's Index of Democracy, the Democracy Barometer, the Varieties of Democracy (V-Dem) Project and so on. (Fuchs - Roller 2018; Högström 2011). Fuchs and Roller (2018) argue that in order to understand the quality of democracy, subjective measures, including the opinions of citizens, should be taken in consideration. In some cases, the indexes on the quality of democracy also include subjective 
measures such as citizens' confidence in the legal system. However, the scores of subjective measures and objective measures can vary substantially (Fuchs Roller 2018). The stability and functioning of democracy in the end depend on citizens' support for democracy, which is composed of their support for democratic values and principles, democratic regimes and political authorities (Fuchs and Roller 2018).

\section{The quality of democracy in Slovenia and Montenegro: "Objective" measures}

In the next section, we will compare the quality of democracy in Slovenia and Montenegro by making an overview of some of the most commonly used indexes that measure quality of democracy (see Table 1). The Nations in Transit index measures how democratic those states that went through transition in the 1990s are. Their democracy score is composed of seven different dimensions (Nations in Transit 2020):

1) National democratic governance, operationalised with a democratic and stable governmental system; an independent, effective and accountable legislature and executive branch and military and security services that are subject to democratic oversight.

2) The electoral process, expressed in regular, free and fair elections, fair electoral laws and equal campaigning opportunities; the absence of barriers to political organization and registration; a multiparty electoral system with opposition parties; public engagement in political life; openness to minority groups in political participation; opportunities for the effective rotation of power; free choice and free and fair judgment of both the presidential and legislative elections.

3) Civil society; seen in the protection of the rights of an independent civil society; a vibrant civil society; the absence of excessive influence from extremist and intolerant organisations; a legal and regulatory environment free of excessive state pressures and bureaucracy; sufficient organizational capacity to work; financially viable with opportunities for fundraising and work; respect from the government for policy advocacy and from the media; the right to form and join free trade unions and an education system free of political influence and propaganda.

4) An independent media, operationalised with legal protection for press freedoms, where journalists are protected from persecution; opposition to onerous libel laws which are free from interference from the government or private owners; a diverse selection of sources of information; privately owned media; the financial viability of private media subject only to market forces; the distribution of newspapers being privately controlled; a professional associations of journalists and free access to and use of the internet. 
5) Local democratic governance, where principles are enshrined in law and respected in practice; local leaders are selected via free and fair elections; meaningful participation of citizens in local government decision-making; the free and autonomous exercise of power; adequate resources and capacity as needed by local authorities to fulfil their responsibilities and operate with transparency and accountability to citizens.

6) The judicial framework and independence, by protection for fundamental political, civil and human rights; respect for fundamental rights in practice; independence and impartiality in the interpretation and enforcement of the constitution; equality before the law; effective reform of criminal law; suspects and prisoners being protected in practice against arbitrary arrest, detention without trial, searches without warrants, torture, abuse and excessive delays in the criminal justice system; judges being appointed in fair and unbiased manner, judges ruling fairly and impartially and courts free of political control and influence, where authorities comply with judicial decisions.

7) Corruption being prevented through the implementation of effective anticorruption initiatives; a country's economy free of excessive state involvement; a government free from excessive bureaucratic regulation, registration requirements and other barriers that increase opportunities for corruption; significant limitations on the participation of government officials in economic life; adequate laws requiring financial disclosure and preventing any conflict of interest; government advertisements for jobs and contracts; a state which enforces effective legislative and administrative process to prevent, investigate and prosecute corruption on the part of government officials and civil servants; whistle-blowers, anticorruption activists, investigators, and journalists enjoying legal protections; any allegations of corruption are given wide and extensive airing in the media and the public displays a high intolerance for official corruption.

Each dimension is measured by set of yes and no questions. The ratings are prepared by Freedom House, academic advisers and country experts. Democracy scores show the average of the ratings for all seven dimensions. The values range from one to seven, where 1 represents the lowest level of democratic progress and 7 the highest (Nations in Transit 2020).

Slovenia scores better than Montenegro on all dimensions and overall, although both countries received the lowest scores in the domain of corruption. The democratic score for Slovenia is 5.93 which ranks it among consolidated democracies that closely embody the best policies and practices of liberal democracies, but which face challenges with corruption. It scores highest at the dimension of the electoral process and local democratic governance and lowest on the dimension of corruption. The highest scores in Montenegro is awarded 
to the dimension of civil society, while as already said, the lowest is for corruption. Overall, in 2019, the value of democratic score was 3.86, which classifies Montenegro as transitional/hybrid regime, being those electoral democracies that meet only minimum standards for the selection of national leaders and in which the democratic institutions are fragile, with substantial challenges to the protection of political rights and civil liberties (Nations in Transit 2020).

$V$-Dem project measures democracy using a liberal democracy index that includes liberal and electoral aspects of democracy, an electoral democracy index that includes indicators on suffrage, elected officials, clean elections, freedom of association, freedom of expression and alternative sources of information, a liberal component index that includes indicators on equality before the law as well as an individual liberty index, a judicial constraints on the executive index and a legislative constraints on the executive index. Besides the electoral and liberal principles of democracy, the V-Dem project also measures the participatory, deliberative and egalitarian principles of democracy. The egalitarian component index includes indicators on equal protection, equal access and equal distribution of resources. The participatory component index includes data on civil society participation, the direct popular vote, local government and regional government. The deliberative component index includes information on reasoned justification, common good, respect for counterarguments, range of consultation and an engaged society. Approximately half of the data is obtained from factual information available in official documents: constitutions and government records. The other half is based on the subjective assessments of country experts. Slovenia is among the top $10-20 \%$ of countries in the liberal democracy index, which classifies it as liberal democracy with some shortcomings. Montenegro is in the range of $40-50 \%$ of the analysed countries, along with Bosnia and Herzegovina, Kosovo and North Macedonia, and is classified as an electoral autocracy. On the other five principles of democracy, Slovenia also scores better than Montenegro. Slovenia scores highest on the participatory component index where it ranks 4 th and lowest on the electoral democracy index where it ranks 29th. Montenegro also scores highest on participatory component index being ranked 46th and lowest on the electoral component index, where it was ranked 107th (Lührmann et al. 2019).

The Polity IV project forms a composite index of regime types and monitors changes to regimes. It measures key qualities of executive recruitment, constraints on executive authority and political competition and changes in the institutionalized qualities of governing authority. However, the data includes information only on the institutions of the central government and the political groups within the authority. Polity IV looks at the same time at the qualities of democracy and autocratic authority in governing institutions. This forms an index of governing authority that spans from fully institutionalized autocracies through mixed and incoherent authority regimes to fully institutionalized 
democracies. Index ranges from -10 - a hereditary monarchy to $+10-a$ consolidated democracy. The regime of the country is defined based on the score of the index: 10 is a full democracy, 6 to 9 a democracy, 1 to 5 an open anocracy, 0 to -5 a closed anocracy and -6 to -10 an autocracy (Polity IV 2018). Both Slovenia and Montenegro are evaluated as democracies. Slovenia scores 10 as a full democracy while Montenegro scores 9 .

The Democracy Index by the Economist Intelligence Unit measures the state of democracy in a composed index of weighted averages, based on the answers to 60 indicators in five different categories: the electoral process and pluralism, the functioning of government, political participation, political culture and civil liberties. Most answers to the indicators are provided by experts, with some taken from public opinion surveys. The answers are standardised on a scale from 0 to 1 . The democracy index scores are calculated from the average values of the five category indices and rounded to two decimal places. Economic living standards are not included as one of the indicators of the democracy index. Based on their ranking, countries are categorised in one of four regime types: 1) full democracies, where civil liberties and basic political freedoms are reinforced by the political culture, the country has a valid system of governmental checks and balances, an independent judiciary, an adequately functioning government and a diverse and independent media; 2) flawed democracies; where elections are free and fair and basic civil liberties are respected with a few issues, but which have an underdeveloped political culture, low levels of political participation and issues in the functioning of governance; 3) hybrid regimes, where irregularities are present in elections, government puts pressure on political opponents, and which feature non-independent judiciaries, widespread corruption, the harassment of media, anaemic rule of law processes, an underdeveloped political culture, low levels of political participation and issues in the functioning of government and 4) authoritarian regimes, where political pluralism has almost vanished, infringements and abuses of civil liberties are common, there is an absence of free and fair elections, the media is state-owned, the judiciary is not independent, and there is censorship and suppression of government criticism (Economist Intelligence Unit 2019). Slovenia scores 7.50 on the democracy index which classifies it as a flawed democracy. It scores the lowest on the index of political culture and highest on the index of the electoral process and pluralism (9.58). Montenegro scores 5.74 and is classified as a hybrid regime. It also scores lowest on the index of political culture and highest on the index of civil liberties (6.76).

The Bertelsmann Stiftung's Transformation Index (BTI) measures two indexes: a Status index that ranks countries according to the quality of their democracy under the rule of law and social market economic practices and a Governance index that ranks countries according to the quality of the leadership's political management performance. Country experts evaluate the extent to which differ- 
ent criteria have been met by responding to a set of questions in a qualitative way that is later standardised into numerical ratings from one, the lowest value to ten, the highest. The Status index is composed of two indexes: 1) the state of political transformation which is assessed based on 5 criteria: a) stateness - the state's monopoly on the use of force and the basic administrative structure, state identity and non-interference of religious dogmas, b) political participation expressed in free and fair elections, effective power to govern, rights of association and freedom of expression, c) the rule of law including the separation of powers, an independent judiciary, civil rights and the prosecution of abuse of office, d) stability: the performance and commitment of democratic institutions and e) political and social integration which includes the party system and interest groups but also measures social capital and the approval of democratic norms and procedures, and 2) the state of economic transformation index measured in 7 criteria: a) the level of socioeconomic development, b) the organization of the market and competition including market-based competition, anti-monopoly policies and the liberalization of foreign trade and banking system, c) currency and price stability, d) private property including property rights and private enterprise, e) a welfare regime which includes social safety nets and equality of opportunity, f) economic performance and g) sustainability expressed in terms of the environmental and education policies. The Governance index is measured by five additional criteria: a) the level of difficulty calculated from three qualitative and three quantitative indicators of structural constraints, difficult conditions and scarcity of resources, b) the steering capability measured in prioritization, implementation and policy learning, c) resource efficiency expressed in the wise and effective use of resources, d) consensus building by building the broadest possible consensus and e) international cooperation seen as reliable work with external supporters and neighbouring states. Aside from the answers of country expert, a second country expert reviews the scores (BTI 2018). Slovenia ranks sixth on the Status index and tenth on the Governance index, while Montenegro scores $20^{\text {th }}$ on the Status index and $17^{\text {th }}$ on the Governance index.

Regardless of which index we use, we may notice that they include various dimensions and sub-dimensions. The composition of indexes is thus complex and the effect of one individual sub-dimension on the whole index is fairly minimal. Montenegro scores below Slovenia on all indexes, but usually on the sub-dimensions of indexes which demonstrate higher levels of quality of democracy, the same applies to Slovenia. Similarly, on those indexes where Slovenia demonstrates lower levels of quality of democracy the same could be said for Montenegro. It seems that the same trends apply to both Slovenia and Montenegro, except that Montenegro needs more time to improve its level of democracy on separate dimensions. At the same time, we may also notice that some indexes evaluate both Slovenia and Montenegro quite high, leaving little 
space for improvement (e.g. the Polity IV index) while others rank both countries quite low, where it seems both will have to further work on improving the quality of their democracy (e.g. the V-Dem project index).

\section{Table 1: Overview of different indexes of the quality of democracy ${ }^{2}$}

\begin{tabular}{|c|c|c|}
\hline Index & Slovenia & Montenegro \\
\hline \multicolumn{3}{|c|}{$\begin{array}{l}\text { Nations in transit, 2020; values from } 1 \text { to } 7 \text {, with } 1 \text { representing the lowest level of democratic } \\
\text { progress and } 7 \text { the highest }\end{array}$} \\
\hline $\begin{array}{l}\text { National } \\
\text { Democratic } \\
\text { Governance }\end{array}$ & 5.75 & 3.25 \\
\hline Electoral Process & 6.50 & 4.25 \\
\hline Civil Society & 6.00 & 5.25 \\
\hline Independent Media & 5.50 & 3.25 \\
\hline $\begin{array}{l}\text { Local Democratic } \\
\text { Governance }\end{array}$ & 6.50 & 4.50 \\
\hline $\begin{array}{l}\text { Judicial Framework } \\
\text { and Independence }\end{array}$ & 6.00 & 3.50 \\
\hline Corruption & 5.25 & 3.00 \\
\hline Democracy Score & 5.93 & 3.86 \\
\hline \multicolumn{3}{|c|}{ V-Dem project, 2019; rank and score from 0 to 1, with 1 representing higher quality } \\
\hline $\begin{array}{l}\text { Liberal Democracy } \\
\text { Index }\end{array}$ & $19 / 0.773$ & $97 / 0.349$ \\
\hline $\begin{array}{l}\text { Electoral } \\
\text { Democracy Index }\end{array}$ & $29 / 0.824$ & $107 / 0.456$ \\
\hline $\begin{array}{l}\text { Liberal Component } \\
\text { Index }\end{array}$ & $7 / 0.975$ & $82 / 0.699$ \\
\hline $\begin{array}{l}\text { Egalitarian } \\
\text { Component Index }\end{array}$ & $17 / 0.899$ & $58 / 0.731$ \\
\hline $\begin{array}{l}\text { Participatory } \\
\text { Component Index }\end{array}$ & $4 / 0.748$ & $46 / 0.605$ \\
\hline $\begin{array}{l}\text { Deliberative } \\
\text { Component Index }\end{array}$ & $27 / 0.900$ & $98 / 0.663$ \\
\hline \multicolumn{3}{|c|}{$\begin{array}{l}\text { Polity IV, } 2014 \text {; scores between }-10 \text { to } 10 \text {, where } 10 \text { is full democracy, } 6 \text { to } 9 \text { democracy, } 1 \text { to } 5 \text { open } \\
\text { anocracy, }-5 \text { to } 0 \text { closed anocracy and }-10 \text { to }-6 \text { autocracy }\end{array}$} \\
\hline Authority trends & 10, since 1991 & 9, since 2006 \\
\hline
\end{tabular}

2 One additional index of the quality of democracy is the Democracy Barometer Index which is built upon liberal and participatory ideas of democracy. It is based on three fundamental principles: freedom, equality and control. The Democracy Barometer, unlike Freedom House, the V-Dem project, the Polity Project and the Bertelsmann Transformation Index, does not rely heavily on expert opinion and rather uses factual data and aggregated survey data (Merkel et al. 2018). Unfortunately, not all indicators are available for all countries. For Montenegro, we only have available data for the principle of equality where Montenegro scores behind Slovenia. For this reason, we did not include the Democracy Barometer Index in the analysis. 


\begin{tabular}{|c|c|c|}
\hline \multicolumn{3}{|c|}{$\begin{array}{l}\text { The Economist Intelligence Unit Democracy index, 2018; rank and scores between } 0 \text { to } 10 \text {, where } 0 \text { to } \\
4 \text { are authoritarian regimes, } 4.01 \text { to } 6 \text { hybrid regimes, } 6.01 \text { to } 8 \text { flawed democracies and } 8.01 \text { to } 10 \text { full } \\
\text { democracies }\end{array}$} \\
\hline $\begin{array}{l}\text { Electoral process } \\
\text { and pluralism }\end{array}$ & 9.58 & 6.08 \\
\hline $\begin{array}{l}\text { Functioning of } \\
\text { government }\end{array}$ & 6.79 & 5.36 \\
\hline $\begin{array}{l}\text { Political } \\
\text { participation }\end{array}$ & 6.67 & 6.11 \\
\hline Political culture & 6.25 & 4.38 \\
\hline Civil liberties & 8.24 & 6.76 \\
\hline Regime type & $36 / 7.50$ & $81 / 5.74$ \\
\hline \multicolumn{3}{|c|}{$\begin{array}{l}\text { Bertelsmann Stiftung Transformation Index, 2018, rank and score between } 1 \text { and } 10 \text { where } 10 \text { is the } \\
\text { highest value }\end{array}$} \\
\hline Status Index & $6 / 9.18$ & $20 / 7.35$ \\
\hline $\begin{array}{l}\text { Political } \\
\text { Transformation }\end{array}$ & $6 / 9.25$ & $26 / 7.55$ \\
\hline $\begin{array}{l}\text { Economic } \\
\text { Transformation }\end{array}$ & $4 / 9.11$ & $23 / 7.14$ \\
\hline Governance Index & $10 / 6.78$ & $17 / 6.49$ \\
\hline
\end{tabular}

Source: BTI 2018; Economic Intelligence Unit 2019; Lührmann et al. 2019; Nations in Transit 2020;

Polity IV 2018.

Various indexes that measure the quality of democracy show higher scores and better ratings for Slovenia. Regardless of which index we take into account or on which dimension of quality of democracy we focus, Slovenia seem to reach higher levels of quality of democracy.

\section{The quality of democracy in Slovenia and Montenegro: "Subjective" measures}

Since most of the composed indexes of the quality of democracy are predominantly based on objective factors, we also looked at public opinion data on satisfaction with democracy, the government and certain other areas (see Table 2). Here the results are not so straight forward. Slovenians trusted their political parties and parliament more compared to Montenegro only in 2008. In 2018, the situation was reversed. Citizens of Montenegro had a higher level of trust in parliament, political parties and trade unions and greater confidence in their government, parliament and political parties. They also had greater trust in the European Parliament and confidence in the European Union in 2018. On the other hand, Slovenians had greater confidence in environmental organisations and the social security system in 2008 , as well as in 2018. Trust in the armed forces dropped between 2008 and 2018 in Slovenia, while in Montenegro, trust in the armed forces increased. With the economic and financial crises 
from 2008 onwards, Slovenia also experienced political crises with a string of early elections in 2011, 2014 and 2018 and new political parties that repeatedly disappointed the voters. This is apparently reflected in dropping trust and confidence in political institutions not only at the national, but also at the EU level. By contrast, in Montenegro where the ruling party since independence is a successor party to the former Montenegrin Communist Party, trust levels in political institutions are higher than in Slovenia.

Slovenians are on the other hand more satisfied with the state of their democracy, find their country to be more democratically governed and are more satisfied with the way democracy works in Slovenia. However, the differences are only minor. At the same time, it seems that for the citizens of Montenegro in general democracy as a political system has a better image. In their view, the democratic system for governing their country is doing better than the system in Slovenia in the opinion of the Slovenians, and Montenegrins are more satisfied with how their political system functions, believing to a greater extent that their political system allows people like them to have an influence on politics.

It seems as though we have some contradictory results. The objective measures of the quality of democracy rate Slovenia higher compared to Montenegro. In addition, according to public opinion, Slovenians express greater satisfaction with democracy in general. But when evaluating the performance of the political system and individual institutions, Montenegrins are more satisfied. This difference between Montenegro and Slovenia was not present only in 2008, which we could explain in terms of Montenegrin satisfaction as a result of enthusiasm over the change of political system and recently won independence. The difference is even more obvious in 2018, more than 10 years after the emergence of an independent Montenegro.

This shows us that by only considering the various indexes of the quality of democracy we may not have an in-depth view in the real state of democracy. While various indexes on the quality of democracy are good for ranking countries and for monitoring progress they do not give us information on where the shortcomings of the quality of democracy are or why they exist. For this reason, we believe case studies on particular policy areas such as the party system, the composition of government, social and defence policy, interest groups and Europeanisation processes should give us a better view of where the differences in the quality of democracy lie in specific areas and perhaps also which processes and factors have contributed to these differences. 
Table 2: Subjective measures of the quality of democracy

\begin{tabular}{|c|c|c|c|}
\hline $\begin{array}{r}\text { Subjective measures of dimensions of the qu } \\
\text { va }\end{array}$ & of dem & EVS, 2008 & d 2018; mean \\
\hline Variable & Year & Slovenia & Montenegro \\
\hline \multirow{2}{*}{$\begin{array}{l}\text { How good is it to have a democratic political system to } \\
\text { govern this country? } \\
\text { (1- very good, } 4 \text { - very bad) }\end{array}$} & 2008 & 1.81 & 1.72 \\
\hline & 2018 & 1.65 & 1.60 \\
\hline $\begin{array}{l}\text { Democracy may have problems but it's better than any } \\
\text { other form of government (1- agree strongly, 4- disagree } \\
\text { strongly) }\end{array}$ & 2008 & 1.92 & 1.76 \\
\hline $\begin{array}{l}\text { How important is it for you to live in a country that is } \\
\text { governed democratically? (1- not at all important, } \\
\text { 10- absolutely important) }\end{array}$ & 2018 & 8.12 & 8.05 \\
\hline $\begin{array}{l}\text { How satisfied are you with democracy? (1- very satisfied, } \\
\text { 4- not at all satisfied) }\end{array}$ & 2008 & 2.55 & 2.73 \\
\hline $\begin{array}{l}\text { And how democratically is this country being governed } \\
\text { today? (1- not at all democratic, 10- completely } \\
\text { democratic) }\end{array}$ & 2018 & 5.38 & 5.18 \\
\hline $\begin{array}{l}\text { On the whole, how satisfied are you with the way } \\
\text { democracy works in your country? (00- extremely } \\
\text { dissatisfied, } 10 \text { - extremely satisfied) }\end{array}$ & 2018 & 4.30 & 4.16 \\
\hline $\begin{array}{l}\text { People have different view about the system for } \\
\text { governing this country. How well things are going? } \\
\text { (1- very bad, 10- very good) }\end{array}$ & 2008 & 4.73 & 5.25 \\
\hline $\begin{array}{l}\text { How satisfied are you with how the political system is } \\
\text { functioning in your country these days? (1- not satisfied } \\
\text { at all, 10- completely satisfied) }\end{array}$ & 2018 & 4.13 & 5.05 \\
\hline $\begin{array}{l}\text { How much would you say that the political system in } \\
\text { your country allows people like you to have an influence } \\
\text { on politics? (1- not at all, 5- a great deal) }\end{array}$ & 2018 & 1.89 & 2.03 \\
\hline \multirow{2}{*}{ Confidence in government (1- a great deal, 4- none at all) } & 2008 & 2.70 & 2.77 \\
\hline & 2018 & 3.10 & 2.79 \\
\hline \multirow{2}{*}{ Confidence in: parliament (1- a great deal, 4- none at all) } & 2008 & 2.60 & 2.80 \\
\hline & 2018 & 3.07 & 2.80 \\
\hline $\begin{array}{l}\text { Trust in national parliament (00- no trust at all, } 10- \\
\text { complete trust) }\end{array}$ & 2018 & 3.58 & 4.16 \\
\hline \multirow{2}{*}{$\begin{array}{l}\text { Confidence in: political parties (1- a great deal, 4- none } \\
\text { at all) }\end{array}$} & 2008 & 2.90 & 3.19 \\
\hline & 2018 & 3.38 & 2.93 \\
\hline $\begin{array}{l}\text { Trust in political parties (00- no trust at all, } 10 \text { - complete } \\
\text { trust) }\end{array}$ & 2018 & 2.70 & 3.07 \\
\hline \multirow{2}{*}{$\begin{array}{l}\text { Confidence in: European union (1- a great deal, 4- none } \\
\text { at all) }\end{array}$} & 2008 & 2.30 & 2.62 \\
\hline & 2018 & 2.84 & 2.46 \\
\hline $\begin{array}{l}\text { Trust in the European Parliament ( } 00 \text { - no trust at all, } \\
10 \text { - complete trust) }\end{array}$ & 2018 & 3.84 & 4.80 \\
\hline \multirow{2}{*}{ Confidence in trade unions (1- a great deal, 4- none at all) } & 2008 & 2.51 & 2.97 \\
\hline & 2018 & 3.03 & 2.95 \\
\hline
\end{tabular}


Subjective measures of dimensions of the quality of democracy, EVS, 2008 and 2018; mean values

\begin{tabular}{|l|c|c|c|}
\hline Variable & Year & Slovenia & Montenegro \\
\hline $\begin{array}{l}\text { Confidence in environmental organizations (1- a great } \\
\text { deal, 4- none at all) }\end{array}$ & 2008 & 2.22 & 2.68 \\
\cline { 2 - 4 } & 2018 & 2.49 & 2.72 \\
\hline $\begin{array}{l}\text { Confidence in: social security system (1- a great deal, } \\
\text { 4- none at all) }\end{array}$ & 2008 & 2.49 & 2.55 \\
\cline { 2 - 4 } & 2018 & 2.61 & 2.74 \\
\hline $\begin{array}{l}\text { Confidence in: the armed forces (1- a great deal, 4- none } \\
\text { at all) }\end{array}$ & 2008 & 2.33 & 2.75 \\
\cline { 2 - 4 } & 2018 & 2.53 & 2.40 \\
\hline
\end{tabular}

Source: EVS 2016; EVS 2018; ESS 2018.

\section{Methodology and content of the special issue}

Despite the common history of Slovenia and Montenegro between 1945 and 1991 and the fact that both are fairly small countries, the quality of democracy in both countries differs today. There may be several reasons for the different paths and speeds of development and transition in both countries. The factors that have influenced successful democratic transition probably also have an effect on the current quality of democracy these countries have achieved.

This special issue on (de)democratisation in Slovenia and Montenegro answers questions about the quality of democracy in these two countries by looking at the specific areas and factors that were on the one hand influenced by the respective processes of democratic transition and on the other, which still contribute to the current state of democracy in both countries.

We will point out a few differences, recognised in the literature, that might have contributed to the changes in the quality of democracy that are still noticeable today. Some of the factors that might have had an impact on the level of the quality of democracy include socio-economic variables, differences in ethnic structure, the strength of civil society, the characteristics of the transition processes, constitutional choices, the electoral system and external factors (Fink Hafner - Hafner Fink 2009).

Year of independence. While Slovenia decided to seek full independence in the early 1990s, Montenegro established, together with Serbia, the Federal Republic of Yugoslavia and gained its independence only in 2006 (see Table 3). The process of transition did not start before 1997 which meant a delay in transitional elections and democratisation (Fink Hafner - Hafner Fink 2009). We consider this factor in all the articles of the special issue, because the total period since independence allowed more time for development in Slovenia. 
Political system. Democratic transitions are less successful in presidential systems and fragmented party system (Przeworski et al. 1996). Although Slovenia and Montenegro both have a parliamentary system, it is characteristic of Montenegro that it has a predominant party system. The former Montenegrin Communist Party renamed itself as the Democratic Party of Socialist and has continued to win national elections since independence. It has control over access to public resources and decision-making and has reinforced a hierarchical political culture in the country and a top-down approach to decision making (Komar - Živković 2016). Elena Nacevska and Nemanja Stankov (2020) fill the gap regarding the differences in the democratization processes between Slovenia and Montenegro with a focus on party system development and changes from the 'old ruling elite' to the establishment of a multi-party system. With special emphasis on electoral rules and party system developments, they outline the patterns of party competition and party system development, between two different political contexts and link these processes to stages of democratisation.

Ethnic structure. A more homogenous ethnic structure contributes to a more successful transition (Gasiorovski - Power 1998) although ethnic heterogeneity does not necessarily prevent a peaceful transition (Fink Hafner - Hafner Fink 2009). Slovenia is more ethnically homogeneous, while in Montenegro more ethnicities coexist, currently without major conflicts. While Montenegrins are the largest ethnic community they do not represent an absolute majority. Alenka Krašovec and Nemanja Batričević (2020) consider the dynamics of government formation in Slovenia and Montenegro since their formal introduction of multiparty systems (1990-2018) in order to identify numerous factors that contribute to the formation and durability of governments, with a special focus on the effect of party cleavages and party systems characteristics in general.

Civil Society. A vibrant civil society and interest group system that is involved in policymaking is an important internal factor supporting democracy (Fink Hafner - Hafner Fink 2009; Linz - Stepan 1996). Slovenia has very vibrant civil society and interest group system which actually started to develop in the 1980s (Kolarič et al. 2002; Vandor et al. 2017). Unlike in Slovenia, Montenegro entered the era of pluralism without being able to develop a participative culture beforehand. Its civil society and interest group system is fairly young and dependent on external funding. There was no opposition civil society that could challenge the old elites at the first multi-party elections (Fink Hafner - Hafner Fink 2009). Olivera Komar and Meta Novak (2020) are in particularly interested in the effects of the democratic transition on the organizational development of the interest group system and their characteristics in Slovenia and Montenegro. They compare the frequency of contacts between interest groups and decision-makers as an indicator of the openness of the political system and the inclusion of members in the internal decision-making of interest groups and argue that established links between interest groups and decision-makers and 
the inclusion of members in interest groups activities contribute to the quality of democracy. In the analyses they use comparative data gathered through a comparative interest groups survey in Slovenia and Montenegro that uses the same research instrument and a similar sampling process, so as to provide comparative data.

External effects. International circumstances have an impact on the development and maintenance of democracy (Fink Hafner - Hafner Fink 2009; Przeworski et al. 1996). Slovenia's earlier independence and better economic position also facilitated their membership of the European Union. Slovenia has been an EU member since 2004 while Montenegro has been a candidate country since 2010. Since 2010, Montenegro has been called many times "a leader" in the EU accession negotiations when is compared to the rest of the region that has not yet joined the EU. It is also true that Slovenia received its status as a candidate country six years after gaining independence (in 1997) while Montenegro was made a candidate country after four years of independence. Gordana Djurović and Damjan Lajh (2020) describe the relationship between Slovenia and Montenegro on the one hand, and the European Union on the other. Both countries held a special status and relationship with the European Communities earlier than most other socialist countries. Economic and social interactions with the EU and its member-states were thus part of Slovenian and Montenegrin life even prior to their independence. Europeanization as a "practical" integration with the EU was closely linked in these two countries to the processes of liberalisation in the economy, society and politics as well as to the processes of democratic transition. The authors investigate the evolution of the relationship between these two countries and the EU.

The economic situation. The economic situation was already different in these two countries while they were both part of Yugoslavia. Slovenia was economically the most developed of all the former Yugoslav republics so its starting point for the democratic transition was better. After all, economic stagnation and a weak economy do not contribute to democratisation (Fink Hafner - Hafner Fink 2009; Przeworski et al. 1996). Even today, GDP per capita is much higher in Slovenia. However, economic development does not generate democracies in and of itself. Other factors need to be present as well (Przeworski 2002). In this special issue, we focus in particular on the effects of the economic situation on social policy. Maša Filipovič Hrast, Uglješa Janković and Tatjana Rakar (2020) examine the diverse developments in the field of social policy over the last three decades. They describe the position and main challenges of the transition of the two countries in the 1990s in relation to developments and changes in the field of social policy, by analysing the main policy changes in the core fields of social policy, such as the labour market and social assistance, family policy and old age policy. In their analysis, they also include a discussion of the structural pressures on social policy, in particular the economic and social situation of 
the two countries, and compare the effects of GDP growth, social stratification, the risk of poverty, social protection expenditure and the unemployment rate.

The presence of war. Peace supports democratic developments and is a necessary condition for a successful transition to democracy (Fink Hafner - Hafner Fink 2009). Neither of these two countries experienced a long war within their territory in the 1990s. Slovenia only experienced a ten-day war. Montenegro was indirectly involved in the war in Bosnia and Herzegovina and Croatia.

Neighbouring countries. Slovenia's geographical position, bordering two more established democracies in Italy and Austria, influenced the culture and their view on free market economies. Having a border with a democratic country has a positive effect on democratic developments (Gasiorowski - Power 1998). The level of democracy in one country interacts with the level of democracy in each neighbouring country (Huntington 1993: 7). On the other hand, Montenegro bordered mostly on the other republics of Yugoslavia. Its only external border was with communist Albania. Iztok Prezelj, Olivera Ignjac and Anja Kolak (2020) explain how democratization of the field of national defence was extremely important since national defence represented one of the cornerstones of the old socialist and communist regimes. The newly independent countries needed to establish themselves in relation towards neighbouring countries by building their own independent system of defence. For Slovenia, the national defence system was challenged already during the first, 10-day long, war of independence. The national defence systems of both countries were a result of their socialist past, but then gradual democratization led to drastic improvements in the quality of democracy in the field of national defence. A more democratic national defence system enabled membership of NATO, the appointment of civilian defence ministers and the inclusion of civilian defence experts, a reduction in the total number of soldiers and the defence budget, the establishment of professional armed forces with a high representation of women and the opportunity to act as a security provider in foreign missions.

The present differences between Slovenia and Montenegro could have contributed to the currently different levels of the quality of democracy in both countries. At the same time, it is also possible that some of the differences are not the cause but rather a consequence of the different levels of the quality of democracy in these two countries.

In this special issue the articles follow the same framework methodology of comparative research. Each article compares the situation in Slovenia and Montenegro by comparing arguments, and the development and characteristics of both countries. In general, the time frame of the analysis extends from the 1980s to the modern day. In their respective articles, the authors present an overview of the development of the particular area and its current situation. The analysis is predominantly descriptive because at the current stage we argue it is necessary to first present the scope of development and the contribution 


\section{Table 3: Factors explaining the differences in the quality of democracy in Slovenia and Montenegro}

\begin{tabular}{|l|l|l|}
\hline Factors & Slovenia & Montenegro \\
\hline Year of independence & 1991 & 2006 \\
\hline Political system & Parliamentary system & Predominant party system \\
\hline Electoral system & Proportional system & Proportional system, closed lists \\
\hline $\begin{array}{l}\text { Ethnic homogeneity of } \\
\text { population. }\end{array}$ & $\begin{array}{l}83.1 \% \text { Slovenes, 2\% Serbs, 1.8\% } \\
\text { Croats, 1.6\% Bosniaks, 0.3\% Italians, } \\
2.2 \% \text { Other, 8.9\% Unspecified (in } \\
2002)\end{array}$ & $\begin{array}{l}44.5 \% \text { Montenegrins; 28.7\% Serbs } \\
0.9 \% \text { Croats, 13.6\% Others ( in 2011) }\end{array}$ \\
\hline $\begin{array}{l}\text { Number of active CSOs / } \\
\text { 1000 citizens }\end{array}$ & 3.62 & 1.69 \\
\hline EU membership status & Member country since 2004 & Candidate country since 2010 \\
\hline $\begin{array}{l}\text { Economic development } \\
\text { (GDP per capita 2018) }\end{array}$ & $€ 20,170$ & $€ 6,230$ \\
\hline $\begin{array}{l}\text { Presence of domestic } \\
\text { war }\end{array}$ & 10 days & indirect \\
\hline $\begin{array}{l}\text { External neighbouring } \\
\text { countries (outside } \\
\text { Yugoslavia) }\end{array}$ & Italy, Austria, Hungary & Albania \\
\hline Membership of NATO & 2004 & 2017 \\
\hline
\end{tabular}

Source: MONSTAT, 2011, SURS, 2002; More-Hollerweger et al. 2019; Eurostat, 2019.

to the quality of democracy from different areas. Although some areas are rich in comparative studies, in other we still lack analysis, especially when we want to compare two small countries with a similar history that took rather different paths towards transition. Where available, the authors also used empirical, comparable data. However, the data is largely comparable in one area but not available to compare it further across different areas. In this special issue, we want to achieve three major goals:

1. To provide an overview of the process of democratic transition in a particular area.

a. In particular, how did the changes arrived at during the process of democratic transition affect the development in the specific area?

2. To evaluate the current quality of democracy in particular areas.

a. What is the current quality of democracy in specific areas and how did it change?

b. Do we currently witness a better quality of democracy or are we starting to notice a process of (de)democratization?

3. To compare the process of democratic transition and the quality of democracy in particular areas in Slovenia and Montenegro 
a. In what ways were the effects of the democratic transition on a specific area similar in Slovenia and Montenegro and in what ways were they different?

b. How different or equal is the quality of democracy in a specific area in Slovenia and Montenegro?

The results produced by these three major goals will produce the first comparative study of the process of democratic transition and democracy in Slovenia and Montenegro.

\section{Conclusion}

This article has examined the definition and different indexes of the quality of democracy and presented their values for Slovenia and Montenegro. We can conclude that scholars have developed a number of composed indexes that include various dimensions of the quality of democracy. Although high scores on one dimension normally also contribute to higher scores on other dimensions there are also some limits to this. It is almost impossible to score the highest values for all dimensions. Nevertheless, Slovenia scores higher in comparison to Montenegro on all indices of the quality of democracy. Although all the objective indexes show a higher level of quality of democracy for Slovenia than for Montenegro, we can also find some similarities in the quality of democracy between the two countries. Slovenia and Montenegro in the majority of cases performed better (or worse) on the same components of the indexes. It seems like that the same trends apply to Slovenia and Montenegro, but that Montenegro needs more time to improve its level of democracy. While the composed indexes that include various dimensions and indicators are very useful for ranking the countries and monitoring their progress they do not tell us much about which the weak points of the quality of democracy are and why these exist.

By also compering the level of satisfaction with democracy in public opinion data we show that subjective measures of quality of democracy are not necessarily dependent on objective measures. All, the indexes of the quality of democracy, regardless of how they are composed, have limitations and do not always tell us the whole story. While objectively the government can propose policies and processes of high democratic quality, citizens may still object to these policies and approaches. Although Slovenians are more satisfied with the state of their democracy, find their country to be more democratically governed and are more satisfied with the way democracy works in Slovenia, Montenegrins in comparison to Slovenians believe that the democratic system for governing their country is doing better, are more satisfied with how the political system is functioning and believe to a greater extent that their political system allows people like them to have an influence on politics. The enthusiasm for the new political system in 
Montenegro has still not decreased after more than 10 years of independence. The level of confidence in political institutions has even increased over the ten years of independence. On the other hand, various political crises in Slovenia are reflected in the low levels of trust in institutions and greater dissatisfaction with the political system.

In this special issue, we will thus offer a case study approach to the assessment of quality of democracy and limit ourselves in each article to a specific area relevant to the quality of democracy such as the party system, government composition, the interest groups system, Europeanisation processes, and social and national defence policies.

The findings are compared between Slovenia and Montenegro, two former Yugoslav republics whose processes of democratic transition have been and remain different. In the future, a similar approach might be used to study the quality of democracy by including other areas, countries or entire regions (e.g. Western Europe) in the analysis. We encourage other scholars to continue to investigate these processes and issues by expending the scope to include other new democracies and geographical areas.

\section{References}

Beetham, David (2004): Democratic Quality: Freedom and Rights Working paper: available at: https://cddrl.fsi.stanford.edu/publications/democratic_quality_freedom_and_rights (26 July 2019).

Bermeo, Nancy (2016): On Democratic Backsliding. Journal of Democracy 27 (1): 5-19.

Bieber, Florian - Solska, Magdalena - Taleski, Dane (2018): Illiberal and Authoritarian Tendencies in Central Southeastern and Eastern Europe, Oxford, Peter Lang.

BTI (2018): Bertelsmann Stiftung's Transformation Index: available at: https://www.bti-project. org/en/data/ (26 July 2019).

Diamond, Larry - Morlino, Leonardo (2004a): The Quality of Democracy. CDDRL Working Papers: available at: https://cddrl.fsi.stanford.edu/publications/the_quality_of_democracy (26 July 2019).

Diamond, Larry - Morlino, Leonardo (2004b): The Quality of Democracy: An Overview. Journal of Democracy 15 (4): 20-31.

Djurović, Gordana - Lajh, Damjan (2020): Relations with the European Union: Comparing Slovenia and Montenegro. Politics in Central Europe Journal 16 (3). Doi: 10.2478/pce-2020-0030.

Economist Intelligence Unit (2019): Democracy Index 2018: Me too? Political participation, protest and democracy, Report, The Economist. 
ESS (2018): European Social Survey Round 9 Data file edition 1. 1. NSD - Norwegian Centre for Research Data, Norway - Data Archive and distributor of ESS data for ESS ERIC. Doi:10.21338/ NSD-ESS9-2018.

Eurobarometer (2019): Eurobarometer interactive. European Commission: available at: https:// ec.europa.eu/commfrontoffice/publicopinion/index.cfm/Chart/index (26 July 2019).

Eurostat (2019): Real GDP per capita: available at: https://ec.europa.eu/eurostat/tgm/table. do?tab=table \& init=1 \& language=en \& pcode=sdg_08_10 \& plugin=1 (5 February 2020).

EVS (2016): European Values Study 2008: Integrated Dataset (EVS 2008), GESIS Data Archive, Cologne, ZA4800 Data file Version 4. 0. 0. Doi:10.4232/1.12458.

EVS (2018): European Values Study 2018: Integrated Dataset (EVS 2018), GESIS Data Archive, Cologne, ZA7500 Data file.

Filipovič Hrast, Maša - Jankovič, Uglješa - Rakar, Tatjana (2020): Social policy in Slovenia and Montenegro: Comparison of development and challenges. Politics in Central Europe Journal 16 (3). Doi: 10.2478/pce-2020-0031.

Fink-Hafner, Danica - Hafner-Fink, Mitja (2009): The Determinants of the Success of Transition to Democracy. Europe-Asia Studies 61 (9): 1603-1625.

Fuchs, Dieter - Roller, Edeltraud (2018): Conceptualizing and Measuring the Quality of Democracy: The Citizens' Perspective. Politics and Governance 16 (1): 22-32.

Gasiorivski, Mark J. - Power, Timothy J. (1998): The Structural Determinants of Democratic Consolidation. Comparative Political Studies 31 (6).

Günay, Cengiz - Dzihic, Vedran (2016): Decoding the authoritarian code: exercising 'legitimate' power politics through the ruling parties in Turkey, Macedonia and Serbia. Southeast European and Black Sea Studies 16 (4): 529-549.

Högström, John (2011): Quality of Democracy: A Comparative Study, paper presented at IPSA-ECPR Joint Conference 16. 2.-19. 2. 2011, Sao Paolo.

Human development reports (2019): Human development data. available at: http://hdr.undp. org/en/data (26 July 2019).

Huntington, Samuel P. (1993): Democracy's Third Wave, in Diamond, Larry - Platter, Mark F. eds., The Global Resurgence of Democracy, 3-25, John Hopkins University Press.

Kolarič, Zinka - Črnak Meglič, Andreja - Vojnovič, Maja (2002): Zasebne neprofitne-volonterske organizacije $v$ mednarodni perspektivi, Fakulteta za družbene vede, Ljubljana.

Komar, Olivera - Živković, Slaven (2016): Montenegro: A Democracy without Alternations. East European Politics and Societies and Cultures 3 (4): 785-804.

Komar, Olivera - Novak, Meta (2020): Introduction: (De)democratisation in Slovenia and Montenegro: Comparing the Quality of Democracy. Politics in Central Europe Journal 16 (3). Doi: 10.2478/pce-2020-0026

Krašovec, Alenka - Batričević, Nemanja (2020): Cleavages and Government in Slovenia and Montenegro. Politics in Central Europe Journal 16 (3). Doi: 10.2478/pce-2020-0027.

Levitsky, Steven - Way, Lucan A. (2010): Competitive Authoritarianism: Hybrid Regimes After the Cold War, Cambridge University Press, Cambridge. 
Lijphart, Arend (1993): Constitutional Choices for New Democracies, in Diamond, Larry - Platter, Mark F. eds., The Global Resurgence of Democracy, 146-158, John Hopkins University Press.

Linz, Juan Jose - Stepan, Alfred (1996): Toward Consolidate d Democracies. Journal of Democ$\operatorname{racy} 7$ (2): 14-33.

Lührmann, Anna - Gastaldi, Lisa - Grahn, Sandra - Lindberg, Staffan I. - Maxwell, Laura Mechkova, Valeriya - Morgan, Richard - Stepanova, Natalia - Pillai, Shreeya (2019): Democracy Facing Global Challenges. V-Dem Annual Democracy Report 2019, V-Dem Institute.

Maloney, William (2009): Interest Groups and the Revitalisation of Democracy: Are we Expecting too Much? Representation 45 (3): 277-287.

Merkel, Wolfgang - Bochsler, Daniel - Bousbah, Karima - Bühlmann, Marc - Giebler, Heiko Hänni, Miriami - Heyne, Lea - Juon, Andreas - Müller, Lisa - Ruth, Saskia - Wessels, Bernhard (2018): Democracy Barometer, Methodology, Version 6. Aarau, Zentrum für Demokratie.

MONSTAT (2011): Census of Population, Households and Dwellings in Montenegro 2011, Statistical office of Montenegro: available at: http://www.monstat.org/userfiles/file/popis2011/ saopstenje/saopstenje(1).pdf (26 December 2019).

More-Hollerweger, Eva - Bogorin, Flavia-Elvira - Litofcenko, Julia - Meyer, Michael, eds. (2019): Civil Society Monitoring in Central and Eastern Europe, Erste Stifung, Vienna.

Nacevska, Elena - Stankov, Nemanja (2020): Development processes of party system changes in Slovenia and Montenegro. Politics in Central Europe Journal 16 (3). Doi: 10.2478/pce-2020-0028.

Nations in Transit (2020): Dropping the Democratic Facade, Freedom House: available at: https://freedomhouse.org/sites/default/files/2020-04/05062020_FH_NIT2020_vfinal.pdf (6. 3. 2020).

Öktem, Kerem - Akkoyunlu, Karabekir (2016): Exit from Democracy: illiberal governance in Turkey and beyond. Southeast European and Black Sea Studies 16 (4): 469-480.

Polity IV (2018): The Polity Project: available at: http://www.systemicpeace.org/polityproject. html (26 July 2019).

Prezelj, Iztok - Injac, Olivera - Kolak, Anja (2020): Democratisation of Defence Policies and Systems in Slovenia and Montenegro: Developmental and Comparative Aspects. Politics in Central Europe Journal 16 (3). Doi: 10.2478/pce-2020-0032.

Przeworski, Adam - Alvarez, Michael - Cheibub, José Antonio - Limongi, Fernando (1996): What Makes Democracies Endure? Journal of Democracy 7 (1): 39-55.

Przeworski, Adam - Alvarez, Michael E. - Cheibub, José Antonio - Limongi, Fernando (2000): Democracy and Development: Political Institutions and Well-Being in the World, 1950-1990, University of Cambridge Press, Cambridge.

Rizman, Rudi (2006): Uncertain Path: Democratic Transition and Consolidation in Slovenia, Texas A \& M University Press.

Schmitter, Philippe (2004): The Quality of Democracy: The Ambiguous Virtues of Accountability. Working paper: available at: https://cddrl.fsi.stanford.edu/publications/the_quality_of_democracy_the_ambiguous_virtues_of_accountability (26 July 2019). 
SURS (2002): Census 2002: 7. Population by ethnic affiliation, Slovenia, Census 1953, 1961, 1971, 1981, 1991 and 2002. Statistical Office of the Republic of Slovenia: available at: https://www. stat.si/popis2002/en/rezultati/rezultati_red.asp?ter=SLO \& st=7 (26 December 2019).

Vandor, Peter - Traxler, Nicole - Millner, Reinhard - Meyer, Michael, eds. (2017): Civil Society in Central and Eastern Europe: Challenges and Opportunities, ERSTE Stiftung Studies, Vienna.

Zakaria, F. (1997): The rise of illiberal democracy. Foreign Affairs (22).

Olivera Komar is Associate Professor at Faculty of Political Science of the University of Montenegro. Her interests include elections, party politics and political behaviour. She is the principal investigator for the Montenegrin National Election Study and the Comparative Electoral System Study for Montenegro (2012, 2016), as well as the national coordinator for European Social Study in Montenegro (2018).

Meta Novak is an Assistant Professor at Faculty of Social Sciences of the University of Ljubljana and a researcher at the same faculty. Her research interests include interest representation, interest groups, civil society, political knowledge, political behaviour, and teaching European content in schools. 